\title{
VISIBLE REFLECTANCE AND CONTENT OF ISOMERIC RATIO OF LYCOPENE IN COMMERCIAL AND ELEVATED LYCOPENE TOMATO VARIETIES BY DIFFERENT TECHNOLOGICAL TRAITS
}

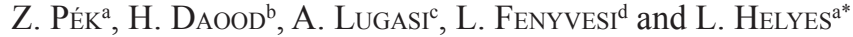 \\ anstitute of Horticulture and Technology, Szent István University, H-2103 Gödöllö, Páter K. út 1. Hungary \\ ${ }^{\mathrm{b} C e n t r a l ~ F o o d ~ R e s e a r c h ~ I n s t i t u t e, ~ H-1022 ~ B u d a p e s t, ~ H e r m a n ~ O t t o ́ ~ u ́ t ~ 15 . ~ H u n g a r y ~}$ \\ ${ }^{\mathrm{c} N a t i o n a l ~ I n s t i t u t e ~ f o r ~ F o o d ~ a n d ~ N u t r i t i o n ~ S c i e n c e, ~ H-1097 ~ B u d a p e s t, ~ G y a ́ l i ~ u ́ t ~ 3 / a . ~ H u n g a r y ~}$ \\ ${ }^{d}$ Hungarian Institute of Agricultural Engineering, H-2100 Gödöllö, Tessedik Sámuel út 4. Hungary
}

(Received: 10 July 2012; accepted: 7 January 2013)

\begin{abstract}
Quantification of red pigment content of fruits using destructive techniques is expensive and it enables only the analysis of batches but not of individual items. This study examined the feasibility of using non-destructive, spectrophotometric method to predict one of the most valuable internal quality indices, lycopene, in individual tomato fruits. An open field experiment was conducted to study the effect of irrigation and potassium supplementation on the yield and lycopene content of processed tomato fruit. Three different treatments (regularly irrigated RI, irrigation cut-off 30 days before harvest $\mathrm{CO}$, and rainfed RF unirrigated control) and two different potassium fertilisations $(\mathrm{P})$ were applied. Regular irrigation significantly decreased the lycopene content of tomato fruits. The $\mathrm{CO}$ treatment resulted in the highest total lycopene without potassium supplementation. Potassium supplementation, given at the time before fruit maturity, significantly increased the lycopene concentration of cultivar Brigade $\mathrm{F}_{1}$, independently of irrigation. The closest correlation was at $700 \mathrm{~nm} \mathrm{R}^{2}=0.38$ and $\mathrm{R}^{2}=0.45$, between reflectance and the (all-E)-lycopene and the $(9 \mathrm{Z})+(13 \mathrm{Z})$-lycopene isomers, respectively.
\end{abstract}

Keywords: tomato, lycopene, (all-E)-, (9Z)-, (13Z)-lycopene isomers, irrigation

The growing interest in nutraceutical compounds produced by tomato plants for their beneficial effects on human health has inspired agronomic research to study aspects regulating the accumulation dynamics and content in the end product, also in relation to both genetic characteristics and crop management, in recent years.

Tomato fruit is an important dietary source of antioxidants, like ascorbic acid, $\beta$-carotene, lycopene, and polyphenols (HELYEs et al., 2007). Ecological conditions have great effect on carotenoid and antioxidant contents of tomato (ABUSHITA et al., 2000). Colour is one of the most important quality components of tomato fruits. The amount of predominant carotenoid, lycopene, which causes the red coloration of fruits, is well characterized by surface reflectance.

Lycopene, as a major carotenoid in tomato, is one of the most potent antioxidants among dietary carotenoids. Dietary intake of tomatoes and tomato products containing lycopene has been shown to be associated with a decreased risk of chronic diseases, such as cancer and cardiovascular disease (WANG, 2012).

Lycopene is accumulated mainly in deep red stage and colour is an indicator of the lycopene level (Brandt et al., 2006; Helyes \& Lugasi, 2006; Helyes et al., 2006c), but the effects of agronomic practices, such as irrigation, on carotenoid accumulation and final amount is still little known, and contrasting results are reported by different authors (DE Pascale et al., 2007; Riggi et al., 2008).

\footnotetext{
* To whom correspondence should be addressed.

Phone: +36 (28) 522-071; fax: +36 (28) 420-804; e-mail: Helyes.Lajos@mkk.szie.hu
} 
Synthesis of lycopene is easily detectable by the non-destructive method of measuring the colour of the fruit surface (Helyes et al., 2006b), and it is also affected by varietal and ecological factors (Dumas et al., 2003; Tomlekova et al., 2007). Chlorophyll breaks down and carotenoids, mostly lycopene, accumulate during ripening (BIACS \& DAOOD, 2000).

Lycopene exists in various geometrical isomers. In most raw fruits the (all-E)-isomer is quantitatively the most important, and within the relatively small proportion of $(Z)$-isomers, (5Z)-, (9Z)-, and (13Z)-lycopene are usually predominant (SCHIERLE et al., 1997). But the $(9 Z)+(13 Z)$-lycopene isomers are more beneficial to human health through their higher antioxidant activity (BöHM et al., 2002) and more bioavailability (BoILEAU et al., 1999) compared to the (all-E)-isomer. The present work elucidated the lycopene content and the isomeric ratio of fresh tomato fruits influenced by variety, irrigation, and potassium supplementation.

\section{Materials and methods}

\subsection{Plant material}

Open field experiment was carried out in the test sites of the Szent István University, Gödöllö in 2008 and 2009. A determined conventional tomato variety Brigade $F_{1}$ and high lycopene cultivars, Triple Red $\mathrm{F}_{1}$, and $\mathrm{UG}$ Red $\mathrm{F}_{1}$ were investigated in the present study. The experimental field, which was $300 \mathrm{~m}^{2}$, is brown forest soil, with the mechanical composition of sand, sandy-clay. The subsoil water is below $5 \mathrm{~m}$, therefore it cannot influence the water turnover. One plot was $25 \mathrm{~m}^{2}$. Growing season was 13 weeks in both years. Tomato seedlings were planted out in twin rows, $0.4 \mathrm{~m}$ spacing inside the raw and $1.2 \mathrm{~m}$ between adjacent twin rows, the space between the plants in the row was $0.4 \mathrm{~m}$.

Drip irrigation was employed according to the evapotranspiration potential. The probable evapotranspiration for the following two or three day intervals were calculated according to the Hungarian Meteorological Service (2010) forecasts. The daily potential evapotranspiration of vegetable crops (tomato) is estimated as follows: the expected daily average temperature divided by five, expressed in millimetres (HelYes \& VARGA, 1994). There were regularly irrigated (RI), irrigation cutoff (CO) plant stands and the rainfed (RF) control and two different potassium fertilisations $(\mathrm{P})$.

Basic nutrition supply was given out when plants were transplanted with Agroblen 188-16 (nitrogen-phosphorus-potassium). Additionally more potassium fertiliser was applied with $\mathrm{KNO}_{3}$ at fruit set, resulting a potassium supply of $555(+\mathrm{K}) \mathrm{kg} \mathrm{ha}^{-1}$.

Five harvested fruits in three replicates were chosen for preliminary spectrophotometric analysis. The spectrophotometric measurements were carried out using a Minolta spectrophotometer at three points in the equatorial region of the tomato fruits. Minolta chroma meter CM-512m3 is a multi-angle spectrophotometer, which uses geometry with D65/10 .

\subsection{Sampling and analysis}

1.2.1. Lycopene by spectrophotometric method. Lycopene contents were established from five fruits in three replicates analysed in the National Institute for Food and Nutrition Science in 2008. Lycopene was extracted from the tomato juice with a mixture of $n$-hexane, methanol, and acetone $(2: 1: 1)$ containing BHT. Optical density of the hexane extract was measured at $502 \mathrm{~nm}$ by a Perkin Elmer Lambda 3B UV Spectrophotometer (Perkin Elmer 
Co., Norwalk, USA) (SADLER et al., 1990). Lycopene concentrations were calculated by applying the molecular extinction coefficient of 158500 (MERCK, 1989). All parameters measured are referred to fresh weight of fruits.

1.2.2. Lycopene by HPLC. Lycopene contents were established from five fruits in three replicates analysed in the Central Food Research Institute in 2009. Five grams of fresh fruits were weighed and crushed in a crucible mortar in the presence of quartz sand with the gradual addition of $20 \mathrm{ml}$ methanol and then was let stand for $5 \mathrm{~min}$. The supernatant was decanted carefully into a $100 \mathrm{ml}$ Erlenmeyer flask. The residues were further crushed and 50 $\mathrm{ml}$ of a 20:60 methanol:1,2-dichloroethane were gradually added. The whole mixture was quantitatively transferred to the Erlenmeyer flask by rinsing twice with $10 \mathrm{ml}$ of the mixture of methanol:1,2-dichloromethane. After gentle hand shaking few drops of double-distilled water were added to enhance the separation of polar (aqueous) and less-polar (solvent) phases. The solvent layer was separated in a funnel and dried over anhydrous $\mathrm{Na}_{2} \mathrm{SO}_{4}$ and then evaporated under vacuum at a temperature of not higher than $40{ }^{\circ} \mathrm{C}$. The residues were re-dissolved in $5 \mathrm{ml}$ of HPLC grade acetone and filtered through a Teflon PTFE $0.45 \mu \mathrm{m}$ syringe filter before injection onto the HPLC column.

Instrument: A Waters HPLC chromatograph consisting of a model 2695 separation module and 2696 photodiode-array detector was used for the analysis of carotenoids. The operation and data processing was performed by Empower software. Column: Nucleodur ISIS C18, $3 \mu \mathrm{m}, 150 \times 4.6 \mathrm{~mm}$ was used.

Detection: Photodiode-array between 190 and $700 \mathrm{~nm}$. For quantification, the chromatogram was integrated at maximum wavelength for each peak using manual integration.

Identification: The peaks were identified by comparing their spectral characteristics and retention times with those of standard materials and with literature data when available (BAUERNFEIND, 1981).

\subsection{Statistical analysis}

The results were expressed as the average plus/minus significant differences at $\mathrm{P}=0.05$. The statistical analysis was carried out by the Student $t$-test, and the statistical analysis was done using the Statistica 9 software.

\section{Results and discussion}

Seasonal variation between the two years was significant in temperature and in amount and distribution of precipitation. Average seasonal temperature was 19.7 and $20.6{ }^{\circ} \mathrm{C}$ during the whole vegetation period, and it was 20.3 and $24.3{ }^{\circ} \mathrm{C}$ during the ripening period in 2008 and 2009, respectively.

Regularly irrigated plants (RI) got $297 \mathrm{~mm}$ irrigation water and $144 \mathrm{~mm}$ precipitation (441 mm together) from the beginning of May, other plants with the cut-off irrigation (CO), which means the irrigation was stopped at the beginning of the ripening process, got $369 \mathrm{~mm}$ water including precipitation, and there was an unirrigated, rainfed control (RF) as well, which got $297 \mathrm{~mm}$ precipitation only in 2008. In 2009, RI plants got $261 \mathrm{~mm}$ irrigation water (417 $\mathrm{mm}$ together with the $156 \mathrm{~mm}$ precipitation), CO plants got $140 \mathrm{~mm}$ irrigation water (296 mm with precipitation), and RF plants got $156 \mathrm{~mm}$ precipitation (Fig. 1). 


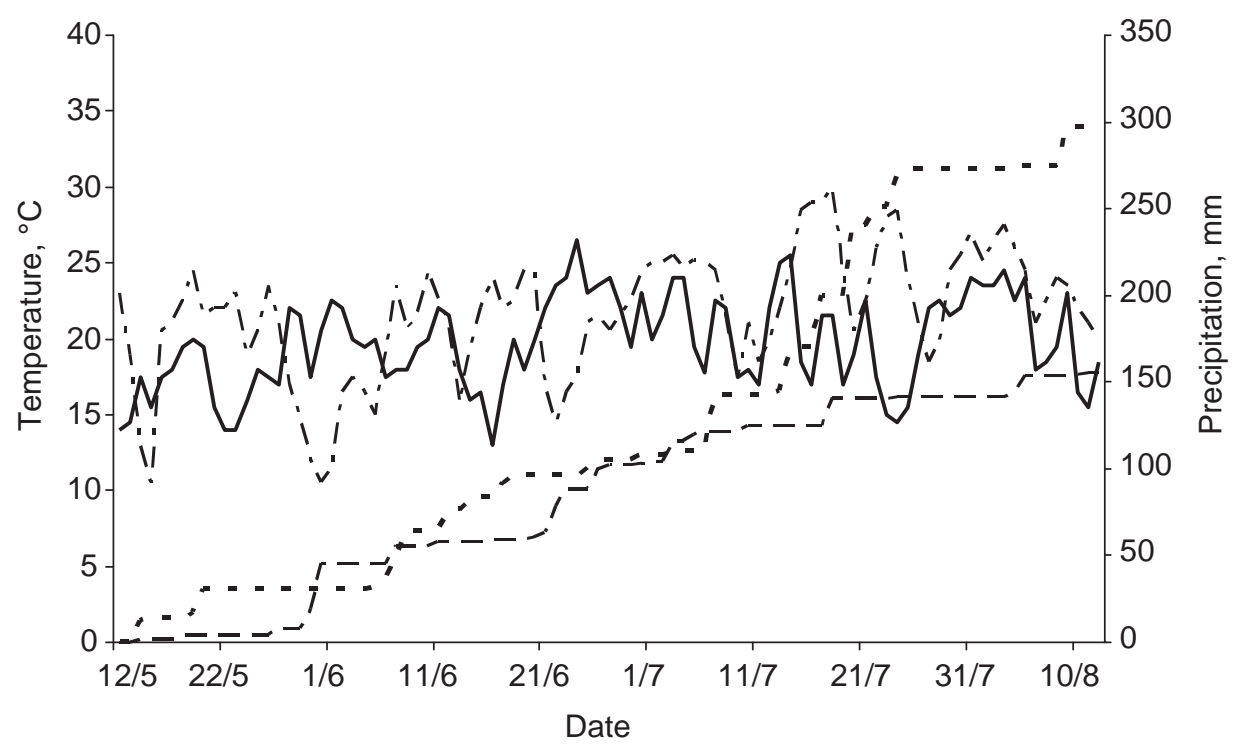

Fig. 1. Meteorological data during tomato vegetation period in 2008 and 2009.

—- Average daily temperature 2008; --.---: average daily temperature 2009;

- - - : accumulated precipitation 2008; - - -: accumulated precipitation 2009

CIELab colour parameters are the most commonly used parameters to indicate the development of red coloration of ripening tomato fruit (PÉK et al., 2011). We established correlation coefficients of linear regression among $\mathrm{a}^{*}, \mathrm{a}^{*} / \mathrm{b}^{*}$, chroma and hue, and fruit surface reflectance between $400-700 \mathrm{~nm}$ in 2008. The closest correlation between chroma and reflectance was at $630 \mathrm{~nm}\left(\mathrm{r}^{2}=0.967\right.$; data not shown), so we used this frequency parameter to evaluate fruit surface colour. Table 1 shows the average lycopene content and surface reflectance at $630 \mathrm{~nm}$ of three hybrid tomato fruits. Regular irrigation significantly decreased the lycopene content of tomato fruits. Lycopene content is fundamentally determined by the genetic factors (CHANDRA \& RAMALINGAM, 2011), but our results show contradictions. Elevated lycopene hybrids (Triple Red $\mathrm{F}_{1}$ ) with irrigation and $\left(\mathrm{Ug} \operatorname{Red~} \mathrm{F}_{1}\right)$ without irrigation did not exceed lycopene content of normal lycopene hybrid (Brigade $\mathrm{F}_{1}$ ). Reflectance data showed the same pattern, so we calculated linear regression between lycopene content and reflectance. Correlations are presented in Fig. 2. With higher lycopene content of fruits higher reflectance values were reached at $630 \mathrm{~nm}$. High lycopene tomato hybrids resulted in more lycopene in the fruits. Triple Red $\mathrm{F}_{1}$ reached the highest lycopene content $(24.3 \mathrm{mg} / 100 \mathrm{~g})$, but not the highest reflectance (UG Red, 31.1\%). In 2009 the same three cultivars were used in the experiments, as in the previous years, supplementing the measurements with the determination of (all-E)-lycopene and (9Z)+(13Z)-lycopene isomer concentrations. The results are shown in Table 2. In year 2009, the cultivars contained less lycopene at harvest than in 2008. This can be explained by the differences in the weather conditions. In 2009, the temperature was higher on average and there was less precipitation at fruit maturity than in 2008 (data not shown). Among the cultivars, Triple Red produced significantly higher total lycopene content than Brigade and UG Red. 
Table 1. Average lycopene content and reflectance at $630 \mathrm{~nm}$ of tomato fruits in 2008 $(\mathrm{n}=3 ; \pm \mathrm{SD})$

\begin{tabular}{|c|c|c|c|c|}
\hline \multirow{2}{*}{ Variety } & \multicolumn{2}{|c|}{ Lycopene content (mg/100 g) } & \multicolumn{2}{|c|}{ Reflectance at $630 \mathrm{~nm}(\%)$} \\
\hline & $\mathrm{RF}$ & RI & $\mathrm{RF}$ & RI \\
\hline Brigade $\mathrm{F}_{1}$ & $17.5 \pm 0.5^{\mathrm{a}}$ & $15.5 \pm 2.4^{\mathrm{ab}}$ & $28.5 \pm 1.6^{\mathrm{ab}}$ & $27.3 \pm 1.8^{\mathrm{a}}$ \\
\hline Triple Red $\mathrm{F}_{1}$ & $22.5 \pm 1.8^{\mathrm{b}}$ & $15.0 \pm 0.7^{\mathrm{a}}$ & $29.6 \pm 0.8^{\mathrm{a}}$ & $27.7 \pm 1.6^{\mathrm{ab}}$ \\
\hline Ug Red $F_{1}$ & $14.9 \pm 1.7^{\mathrm{a}}$ & $19.2 \pm 1.9^{\mathrm{b}}$ & $25.0 \pm 1.9^{\mathrm{b}}$ & $29.8 \pm 1.3^{\mathrm{b}}$ \\
\hline
\end{tabular}

Data in the same column bearing the same superscript letter are not significantly different at $\mathrm{P}=0.05$

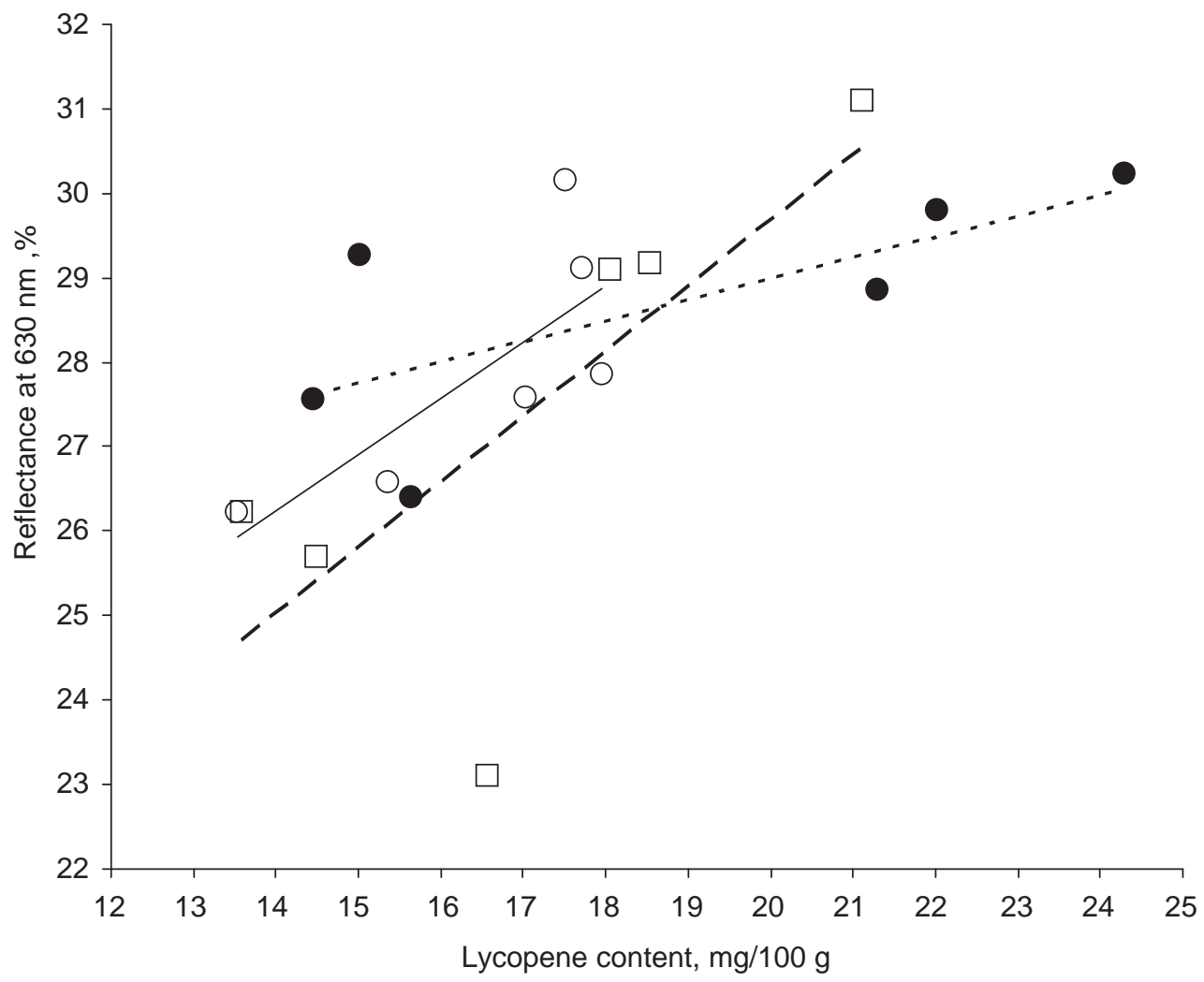

Fig. 2. Correlation between lycopene content and reflectance at $630 \mathrm{~nm}$ of tomato fruits, with function and correlation coefficient of linear regressions $(n=6) . \mathrm{O}$ : Brigade $\mathrm{F}_{1}$; — $\mathrm{y}=0.6628 \mathrm{x}+16.968 ; \mathrm{R}^{2}=0.5942 ; \square: \mathrm{UG}$ Red $\mathrm{F}_{1} ;---: \mathrm{y}=0.7756 \mathrm{x}+14.17 ; \mathrm{R}^{2}=0.5464$;

: Triple Red $F_{1} ;-\cdots:-y^{\prime}=0.2492 x+24.006 ; R^{2}=0.5312$

The irrigation generally decreased the total lycopene content of fruits, except in cultivar Triple Red, where it caused a significantly higher lycopene concentration. The CO treatment without additional potassium resulted in the highest total lycopene content. Potassium supplementation before fruit maturity significantly increased the lycopene concentration of cultivar Brigade, independently of irrigation. The greatest effect of irrigation on lycopene 
could be measured in cultivar Brigade, where it reduced the concentration almost by $50 \%$. The major part of the lycopene content was (all-E)-lycopene, changing between 79.5 and $85 \%$, while the ratio of $(9 Z)+(13 Z)$-lycopene isomers ranged between 15.6 and $20.5 \%$. Irrigation reduced (all-E)-lycopene in cultivars Brigade and UG Red, while in the case of cultivar Triple Red the opposite effect could be observed. Irrigation caused a significant reduction of $(9 Z)+(13 Z)$-lycopene isomers only in the case of cultivar Brigade. Potassium increased the amounts of all lycopene isomers, without irrigation it increased (all-E)-lycopene content to the greatest extent, while under irrigated conditions it was the $(9 \mathrm{Z})+(13 \mathrm{Z})$-lycopene content that was increased.

Table 2. Average carotenoid component of different types of tomatoes with different irrigation and potassium fertilization in $2009(n=3)$

\begin{tabular}{lccccc}
\hline Treatment & $\begin{array}{c}\text { (all-E)-lycopene } \\
(\mu \mathrm{g} / \mathrm{g})\end{array}$ & $\begin{array}{c}(9 \mathrm{Z})+(13 \mathrm{Z})- \\
\text { lycopene } \\
(\mu \mathrm{g} / \mathrm{g})\end{array}$ & $\begin{array}{c}(\text { all-E })+ \\
(9 \mathrm{Z})+(13 \mathrm{Z})- \\
\text { lycopene } \\
(\mu \mathrm{g} / \mathrm{g})\end{array}$ & $\begin{array}{c}\text { (all-E)-lycopene } \\
(\%)\end{array}$ & $\begin{array}{c}(9 \mathrm{Z})+(13 \mathrm{Z})- \\
\text { lycopene } \\
(\%)\end{array}$ \\
\hline Brigade RF & $7.42 \pm 0.13^{\mathrm{d}}$ & $1.70 \pm 0.12^{\mathrm{d}}$ & $9.12 \pm 0.16^{\mathrm{d}}$ & 81.4 & 18.6 \\
Brigade RF P & $8.47 \pm 0.10^{\mathrm{e}}$ & $1.82 \pm 0.11^{\mathrm{de}}$ & $10.29 \pm 0.12^{\mathrm{e}}$ & 82.3 & 17.7 \\
Brigade RI & $4.04 \pm 0.10^{\mathrm{a}}$ & $0.71 \pm 0.11^{\mathrm{a}}$ & $4.75 \pm 0.01^{\mathrm{a}}$ & 85.0 & 15.0 \\
Brigade RI P & $5.74 \pm 0.25^{\mathrm{c}}$ & $1.15 \pm 0.11^{\mathrm{c}}$ & $6.89 \pm 0.21^{\mathrm{c}}$ & 83.3 & 16.7 \\
Brigade CO & $8.11 \pm 0.41^{\mathrm{e}}$ & $1.93 \pm 0.15^{\mathrm{e}}$ & $10.05 \pm 0.47^{\mathrm{e}}$ & 80.7 & 19.3 \\
Triple Red RF & $4.28 \pm 0.01^{\mathrm{b}}$ & $0.97 \pm 0.11^{\mathrm{b}}$ & $5.25 \pm 0.10^{\mathrm{b}}$ & 81.6 & 18.4 \\
Triple Red RI & $5.78 \pm 0.11^{\mathrm{c}}$ & $1.07 \pm 0.06^{\mathrm{bc}}$ & $6.84 \pm 0.08^{\mathrm{c}}$ & 84.4 & 15.6 \\
UG Red RF & $4.34 \pm 0.08^{\mathrm{b}}$ & $1.13 \pm 0.13^{\mathrm{bc}}$ & $5.47 \pm 0.21^{\mathrm{b}}$ & 79.5 & 20.5 \\
UG Red RI & $4.14 \pm 0.27^{\mathrm{ab}}$ & $0.94 \pm 0.08^{\mathrm{b}}$ & $5.09 \pm 0.35^{\mathrm{ab}}$ & 81.5 & 18.5 \\
\hline
\end{tabular}

Data in the same column bearing the same superscript letter are not significantly different at $\mathrm{P}=0.05$

In 2009 we also performed the correlation analysis between the spectral reflectance of fruits and their lycopene content. The results are shown in Fig. 3. The measured reflectance values (400-700 nm) showed a positive correlation at 630-700 nm with the lycopene components, among which the closest were at $700 \mathrm{~nm} \mathrm{R}^{2}=0.38$ and $\mathrm{R}^{2}=0.45$ for the (all-E)-

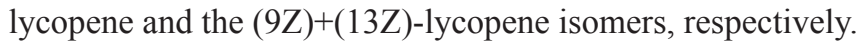

\section{Conclusions}

We managed to prove the quantitative and qualitative changes in lycopene content of raw tomato fruit samples as a result of irrigation and potassium supplementation treatments. In the two consecutive years the lycopene content of fruits differed in all three examined cultivars, which was possibly a result of the differences in the weather conditions. Cooler weather may have caused higher lycopene levels in the tomato fruit, as was concluded previously by HeLYes and co-workers (2006c) and PéK and co-workers (2011). 


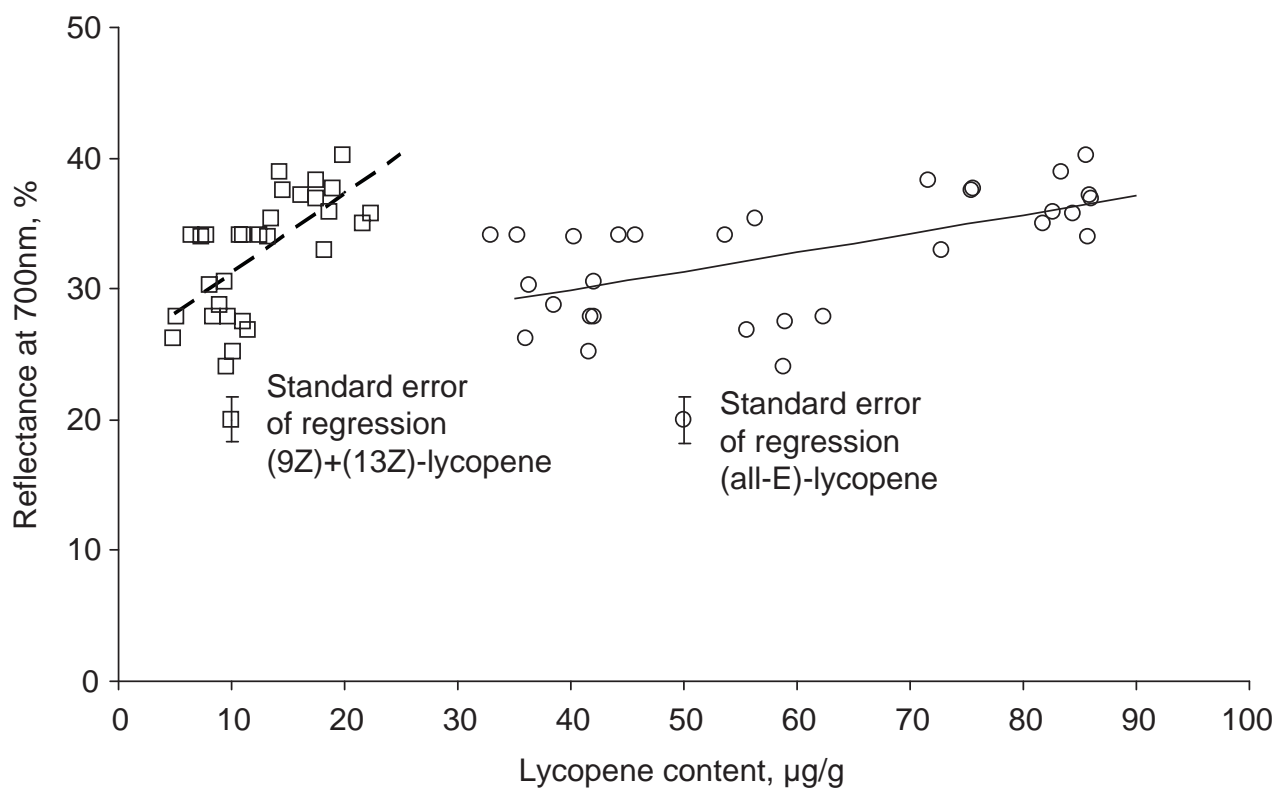

Fig. 3. Correlation between (all-E)-lycopene and (9Z)+(13Z)-lycopene content and reflectance at $700 \mathrm{~nm}$ of tomato fruits, with function and correlation coefficient of linear regressions in $2009(n=30)$.

O: (All-E)-lycopene; —— $\mathrm{y}=0.1435 \mathrm{x}+24.185 ; \mathrm{R}^{2}=0.3759 ; \square:(9 \mathrm{Z})+(13 \mathrm{Z})$-lycopene;

The lycopene content of high lycopene hybrids was higher under irrigated conditions, than that of the traditional cultivars. We have shown that irrigation cutoff, which is an old technological trait used to speed up the rate of maturation, effectively increases the lycopene content of raw fruits. In the case of $(9 Z)+(13 Z)$-lycopene isomers, more beneficial to human health through its higher antioxidant activity (BöHM et al., 2002) and more bioavailability (BoILEAu et al., 1999) compared to all-trans-lycopene, a significant increase was caused by irrigation in high lycopene hybrids compared to traditional cultivars.

Reflectance values measured in the visible range gave closer positive correlation with lycopene content above the $600 \mathrm{~nm}$ range in both years. Based on the results of 2009, it can be concluded that the reflectance values of lycopene isomers are possibly different. Beside this, the correlations are not so close, that the lycopene content of fruits could be determined too accurately by the reflectance of the fruit surface. Further spectrophotometrical experiments are required to fine-tune a nondestructive method of lycopene isomer determination.

This study was funded by TECH-09-A3-2009-0230, USOK2009, and Research Centre of Excellence - 175864/2013/TUDPOL Szent István University and KTIA_AIK_12-1-2012-0012 TÁMOP-4.2.1.B-11/2/KMR-20110003 projects. 


\section{References}

Abushita, A.A., Daood, H.G. \& Biacs, P.A. (2000): Change in carotenoids and antioxidant vitamins in tomato as a function of varietal and technological factors. J. Agric. Fd Chem., 6, 2075-2081.

Bauernfeind, J.C.H. (1981): Carotenoids as colorants and vitamin A precursors. Academic Press, New York, 938 pages.

BiAcs, P.A. \& DAOOD, H.G. (2000): Lipoxygenase-catalysed degradation of carotenoids from tomato in the presence of antioxidant vitamins. Biochem. Soc. Trans., 28, 839-845.

Boileau, A.C., Merchen, N.R., Wasson, K., Atkinson, C.A.\&Erdman JR., J.W. (1999): Cis-lycopene is more bioavailable than trans-lycopene in vitro and in vivo in lymph-cannulated ferrets. J. Nutr., 129, 1176-1181.

Böhm, V., Puspitasari-Nienaber, N.L., Ferruzzi, M.G.\&Schwartz, S.J. (2002): Trolox equivalent antioxidant capacity of different geometrical isomers of $\alpha$-carotene, $\beta$-carotene, lycopene, and zeaxanthin. J. Agric. Fd Chem., 50, 221-226.

Brandt, S., Pék, Z., Barna, É., Lugasi, A.\& Helyes, L. (2006): Lycopene content and colour of ripening tomatoes as affected by environmental conditions. J. Sci. Fd Agric., 86, 568-572.

Chandra, H.M. \& Ramalingam, S. (2011): Antioxidant potentials of skin, pulp, and seed fractions of commercially important tomato cultivars. Fd Sci. Biotechnol., 20, 15-21.

De Pascale, S., Martino, A., Raimondi, G.\& Maggio, A. (2007): Comparative analysis of water and salt stressinduced modifications of quality parameters in cherry tomatoes. J. Hort. Sci. Biotechnol., 82, 283-289.

Dumas, Y., Dadomo, M., Di Lucca, G.\&Grolier, P. (2003): Effects of environmental factors and agricultural techniques on antioxidant content of tomatoes. J. Sci. Fd Agric., 83, 369-382.

Helyes, L. \&VArga, G. (1994): Irrigation demand of tomato according to the results of three decades. Acta Hort., 376, 323-328

Helyes, L.\& Lugasi, A. (2006): Formation of certain compounds having technological and nutritional importance in tomato fruits during maturation. Acta Alimentaria, 35, 183-193.

Helyes, L., Dimény, J., PÉk, Z. \& Lugasi, A. (2006a): Effect of the variety and growing methods as well as cultivation conditions on ingredient of tomato (Lycopersicon lycopersicum (L.) Karsten) fruit. Acta Hort., 712, 511-516.

Helyes, L., Lugasi, A. \& PéK, Z. (2006b): Tomato fruit quality and content depend on stage of maturity. HortScience, $41,1400-1401$.

Helyes, L., Lugasi, A., Pék, Z. \& Brandt, S. (2006c): Analysis of antioxidant compounds and hydroxymethylfurfural in processing tomato cultivars. Horttechnology, 16, 615-619.

Helyes, L., Lugasi, A.\& Pék, Z. (2007): Effect of natural light on surface temperature and lycopene content of vine ripened tomato fruit. Can. J. Pl. Sci., 87, 927-929.

Hungarian Meteorological Service (2010): Weather forecast. http://www.met.hu/idojaras/elorejelzes/

MercK (1989): Merck index. $11^{\text {th }}$ ed, MERCK, Rahway, NJ, USA, 884 p.

Pék, Z., Szuvandzsiev, P., Nemenyi, A., Helyes, L. \& Lugasi, A. (2011): The effect of natural light on changes in antioxidant content and color parameters of vine-ripened tomato (Solanum lycopersicum L.) fruits. HortScience, 46, 583-585.

Riggi, E., Patané, C.\& Ruberto, G. (2008): Content of carotenoids at different ripening stages in processing tomato in relation to soil water availability. Aust. J. Agric. Res., 59, 348-353.

SAdler, G., Davies, J. \& Dezman, D. (1990): Rapid extraction of lycopene and $\beta$-carotene from reconstituted tomato paste and pink grapefruit homogenates. J. Fd Sci., 55, 1460-1461.

Schierle, J., Bretzel, W., Buhler, I., Faccin, N., Hess, D., Steiner, K. \& Schuep, W. (1997): Content and isomeric ratio of lycopene in food and human blood plasma. Fd Chem., 59, 459-465.

Tomlekova, N., Atanassova, B., Baralieva, D., Ribarova, F.\& Marinova, D. (2007): Study on the variability of lycopene and $\beta$-carotene content in tomato (Lycopersicon esculentum Mill.). Acta Hort., 729, 101-104.

WANG, X.D. (2012): Lycopene metabolism and its biological significance. Am. J. Clin. Nutr., 96, 1214S-1222S. 